\title{
Factors Affecting the Implementation of Green Tourism in Da Nang City
}

\author{
Trinh Le Tan ${ }^{1)}$, Ngo Cat Tuong ${ }^{2)}$, Phan Hai Nguyet ${ }^{3)}$, Luu Minh Man ${ }^{4)}$, \\ Hoang Thi Lan $\mathrm{Nhi}^{5)}$, Nguyen Thao Van ${ }^{6)}$ \\ 1), 2), 3), 4), 5), 6) FPT University, Vietnam
}

Email:*letandtu@gmail.com ${ }^{1)}$,tuongnc2520@gmail.com ${ }^{2)}$,phanhainguyetdn@gmail.com ${ }^{3}$, minhmanluu23@gmail.com ${ }^{4)}$, lanhihoang263@gmail.com ${ }^{5)}$, thaovan16012001@ gmail.com ${ }^{6}$

*Corresponding author

\begin{abstract}
This article describes the impact of factors affecting the implementation of Green Tourism as a sustainable tourism type in Da Nang City after the Covid-19 pandemic and in the near future. Today, air pollution and the Covid-19 pandemic are urgent problems that people are facing to overcome and stabilize social life as well as the economy. With the title of Vietnam's National Green City (Danang city's e-portal, 2018), Da Nang - one of the most famous tourist cities in Vietnam, has many favorable conditions for the development of the "green tourism" model, contributing to the development of a sustainable green economy. We use qualitative research to establish the hypotheses in this research. In the quantitative research, data were collected from business owners dealing in accommodation and travel services in the tourism industry in Da Nang city through questionnaires. The data analysis methods used in this study are Cronbach and EFA methods, correlation, and regression. The results show that there are 4 factors: Cost, Green Awareness, Competitive Advantages, and Policy of Government affecting the implementation of the green tourism model in Da Nang. Most of the business owners providing accommodation and travel services in the tourism industry in Da Nang city are aware of the importance and potential of developing "green tourism" in Da Nang in the future.
\end{abstract}

Keywords: Green Tourism, Sustainable Tourism, Danang City, Environmentally Friendly Tourism, Danang's Tourism Industry

\section{Introduction}

"Green tourism" in recent years is not only a concept but has become a trend, and has been developing rapidly in many countries around the world. As reported by 971 responses from an international ecotourism society's September 2019 survey, about 95\% of the respondents almost uniformly agree that ecotourism is growing rapidly (Responses to the International Ecotourism society's September 2019 survey, 2021). Therefore, green tourism is increasingly attracting the wide attention of tourists, tourism businesses in particular, and the social community in general, and green tourism has affirmed its competitiveness.

These days, "green tourism" is not only a guarantee for sustainable tourism development but also a solution to help increase the number of tourists with high spending levels and consciously and civilized actions when participating in tourism. Most visitors intend to stay at least once at an eco-friendly establishment. This rate has increased over the years $(62 \%$ in $2016,65 \%$ in $2017,68 \%$ in $2018,73 \%$ in 2019$) .70 \%$ of travelers said that they will most 
likely book a room at a green property (2019); $52 \%$ of visitors switch to a more eco-friendly mode of travel such as walking, cycling, or hiking when possible; $67 \%$ of travelers are willing to pay at least $5 \%$ more for their trip to limit their environmental impact when possible. Besides, research from Trip Advisor shows that $34 \%$ of travelers are willing to pay extra to stay in eco-friendly hotels; $50 \%$ of international visitors are willing to pay extra for a travel agency that benefits local communities and conservation (Green tourism: A guarantee for sustainable tourism development, 2021).

Keeping up with this trend, the development of green tourism is really necessary, this should also be the long-term orientation for tourism in the unstable environment currently of Vietnam in general and of Danang City - one of the big and famous tourist cities in specific. One of the favorable conditions for the development of green tourism in Da Nang is the fact that Da Nang is awarded the title of "Vietnam National Green City" (Danang city's e-portal, 2018) with rich and diverse cultural tourism resources. On the other hand, Vietnam is a country heavily affected by climate change, so minimizing environmental problems is always a top priority. Therefore, green tourism needs to be developed more strongly, contributing to sustainable green economic development (Green tourism and difficult obstacles, 2019).

However, the current form of green tourism is facing some difficulties and challenges. More and more accommodation and tourist services are built on islands without planning, increasing the risk of coastal erosion and degradation of marine and island ecosystems. Untreated wastewater from accommodation facilities and tourism services is discharged directly into the environment, increasing the organic level of coastal seawater. And yet, the conflict of economic interests between economic actors and industries, short-term vision, and technology limitations have resulted in a number of tourism resources being destroyed and misused (Green tourism and difficult obstacles, 2019).

\section{Literature Review}

\subsection{Theory of "green tourism"}

According to The International Ecotourism Society (TIES), green tourism can be defined as "responsible travel to natural areas, conserving the environment; sustain the lives of local people and relating to education. Such tours can be organized by individuals, companies or tourism organizations; educated on ecological issues." (What is green tourism or ecotourism? Ecotourism trends in the future, 2021).

Developed countries have also announced a green tourism rating system. For example, Ecuador was the first country to recognize the right of nature in the Constitution. Thanks to its efforts, Ecuador was honored to be included in the list of the world's top green tourist destinations at the World Travel Awards for 5 consecutive years and Singapore - a famous country for green - clean tourism. - Beautiful, Singapore is also known as "Green City", "Cleanest City in the World" - Clean because of its ecological environment and very friendly traffic. (Singapore - The green - clean - beautiful tourism country | FOCUS ASIA TRAVEL, 2021; If you love nature, don't miss these 20 green tourist destinations, 2021).

\subsection{Factors affecting the implementation of "Green Tourism"}

\subsubsection{Cost}

Currently, green tourism is still a big challenge for Danang city because of its expensive cost. Therefore, Da Nang has been offering many policies to promote and bring green tourism into 
the community. Specifically, on November 23, 2017, Vice Chairman of Da Nang City People's Committee Nguyen Ngoc Tuan the framework of a meeting with Mr. Nakata Yasuhiro, President of the Japan Traffic Planning Association (JTPA) during the first survey trip of Da Nang City. JTPA in Da Nang aimed at preliminary assessment of the applicability of the Automated Guided Public Transport (AGT) model.

According to Mr. Nakata Yasuhiro, President of the Japan Traffic Planning Association (JTPA), AGT is the optimal solution for the mid-range urban transport system, which has been successfully applied in Tokyo, Yokohama, and Kobe cities. , Osaka (Japan) and Singapore, the United States, Hong Kong... AGT is an overhead transport system, using multi-cabin and rubber-wheeled trains, moving within a range of $5-30 \mathrm{~km}$, the Construction of elevated railway does not incur costs related to site clearance. In addition to the benefits to carry passengers, AGT also helps to increase the value of real estate around the location where the AGT route passes. In particular, the construction cost of AGT is one-third lower than that of subway construction. With modern technology and appropriate maintenance, it can meet the needs of users from 50 years or more up (Japan supports Da Nang to build automatic public transport, 2017).

\section{H1: Cost has a positive effect on the implementation of green tourism in Da Nang City.}

\subsubsection{Green Awareness}

In order to implement strategies and policies to help develop green tourism in Da Nang, we first need to raise the awareness of all people about the importance and potential of this type to the environment, social life, as well as the economy of tourism in the future.

Mr. Nguyen Duc Vu, Head of the Management Board of Son Tra peninsula and Da Nang tourist beaches said: "Recently, we have coordinated with departments and agencies to implement the program "Clean up Son Tra - For a Son Tra Green" to propagate and raise public awareness about environmental protection, biodiversity conservation in Son Tra peninsula and reduce environmental pollution, especially plastic waste. The program has attracted nearly 500 volunteers from Duy Tan University; the University of Economics, University of Education (Da Nang University), and associations and groups such as Son Tra garbage cleaning group, Boy Scouts - Hai Chau, Green trip, Tram Eco, Hand in a hand support group, GEA, Danang runner, etc participated," said Mr. Vu (Discover the 'green' Da Nang, 2021), (Da Nang: Green tourism - The key to sustainable development, 2021).

In addition, it is necessary to raise awareness and train on green tourism, first of all for managers at all levels from state management, corporate governance of the tourism industry, and tourism-related industries. history on the content, meaning, and importance of green tourism development. At the same time, it is necessary to raise awareness, educate and train the community on green tourism development, especially in regions, destinations, and tourist areas (Environmental magazine, 2021).

Protecting the tourism environment, in addition to preserving the green color of nature, is also keeping the "green" color of consciousness, that is the best and only way to make tourism develop sustainably.

H2: Green Awareness has a positive effect on the implementation of green tourism in Da Nang City. 


\subsubsection{Competitive Advantages}

Currently, Vietnam's tourism is developing in a context of many fluctuations, increasing competitive pressure. Many countries in the region have a high level of tourism development, many supportive policies, and socio-economic development creating many favorable conditions for tourism development. What factors, which areas have competitive advantages in tourism, considered in the competitive relationship, we can see some factors that can be considered as important advantages of Vietnam's tourism that need to be focused on. Mining centers in the near future include:

Diversified tourism resources. Vietnam is one of the countries with many natural resources and diverse cultures. Vietnam is a country located in the central region of Southeast Asia. From Vietnam, visitors can easily move and continue their travel journey to other countries in the region.

Diversity of products and services: Tourism products and services in Vietnam are very diverse. From ecotourism, thrills to spiritual tourism, festivals, cuisine... Visitors to Vietnam can easily choose the form of tourism that suits them (Travel Competitor Analysis - CRIF D\&B Vietnam, 2021)

Large labor market. Tourism is the largest employer compared to service industries, not only in the industry but also in society. Vietnam is a country with a large population, in which the young population has a relatively high rate compared to the world and in the region. This labor market is capable of providing abundant human resources for tourism.

The price has a good comparison. Compared with many countries in the region and internationally, the price of goods and services in Vietnam is not too high. This is also one of the important attractive factors for the market. Most of the prices for accommodation, catering, retail shopping, transportation, and communication services are lower than in many other countries.

A gentle, lovable person. Vietnam is a hospitable nation, highly appreciated by many tourists. The people and lifestyle of the people in the regions are one of the available attractions as a competitive advantage of Vietnam's tourism. Vietnam, with 54 ethnic groups, has many ethnic minority communities with different traditions and customs, creating a great attraction for tourists to explore.

Developed traditional professions. Vietnam is a country with a long historical tradition and a diverse system of villages and traditional occupations, many of which are still handed down. Developing traditional occupations in the current modern development is very necessary. Traditional craft villages are the objects of sightseeing and research of tourism activities. Products provided by traditional craft villages such as consumer products, gifts, and souvenirs to tourists can create competitiveness and distinctive features of Vietnam's tourism.

The Central region has a rapid breakthrough in tourism development and clearly shows its competitiveness, focusing on some typical localities such as Da Nang, Thua Thien - Hue, Quang Nam, Khanh Hoa. . The conditions and competitive advantages of these provinces also contribute to the competitiveness of Vietnam's tourism in general (Travel Competitor Analysis - CRIF D\&B Vietnam, 2021).

H3: Competitive Advantages have a positive effect on the implementation of green tourism in Da Nang City. 


\subsubsection{Policy of Government}

In recent years with the deterioration of the environment, the trend of green tourism is increasingly being prioritized by both domestic and foreign tourists. It can be seen that the tourism development policy of the Government is also gradually keeping up with the world's demand for green tourism. To further promote the development of green tourism, the Government needs to issue a "set of green tourism criteria" for tourism businesses to apply in the planning and investment process. In addition, it is also the basis for evaluating "green" products. The Government needs to continue to expand and develop actions on environmental protection and response to climate change. Approaching countries with strong green tourism in "green" knowledge and "green" technology to apply to the development of green tourism in Vietnam. The Government needs to have a plan for intensive training in the green economy and green tourism overseas for professional and managerial staff at all levels. Finally, the Government, as well as businesses, need to step up the promotion of green tourism for the whole society. While raising awareness and propagating the concept of green tourism for the community, it also builds a friendly green tourism image that attracts visitors (Environmental magazine, 2021).

H4: The policy of Government has a positive effect on the implementation of green tourism in Da Nang City.

\subsection{Future potential of green tourism in the context of the covid 19 epidemics}

With the destruction of nature coming from global warming and the consequences that humans are beginning to pay for their actions. And in fact, in addition to natural agents, today there are potential strains of "viruses" that cause global pandemics - Covid19. In the past 2 years, the Covid-19 epidemic has seriously affected the tourism potential of Da Nang in particular and Vietnam in general. And that is also the reason why we should choose green tourism as a type of sustainable tourism in the future. With the desire to change pollution issues in the future, to make many changes in the development plan of Vietnam's tourism industry, green tourism has started to be applied in recent years, especially in Da Nang City. With diverse terrain including mountains, sea, rivers, plains, and ideal climate conditions, in Da Nang, many nature reserves and eco-tourism areas have been formed such as Son Tra Peninsula Nature Reserve. , Than Tai hot spring ecotourism area, etc. These ecotourism areas all possess favorable natural conditions and methodical investment in facilities, infrastructure, and services to become attractive destinations (Discover the 'green'Da Nang, 2021).

In recent years, Da Nang has concentrated on developing the "green tourism" model. In particular, in the project to bring Da Nang towards green growth, the Danang Institute of Socio-Economic Development has proposed a number of necessary projects to develop ecotourism services, creating a variety of tourism products associated with nature and the environment, bringing many options for tourists to visit and relax. The resort relies on nature to exploit tourism services and bring many unique and novel tourism products to visitors such as rafting, boating, zipline, etc. For hotel units, the trend of tourism living in green space is being favored. Therefore, the green space design becomes a sustainable solution for each hotel. Many (hotel) apartments, homestays in the Son Tra district have created green areas, using many objects made from natural materials and bringing green trees into the rooms. Besides, along with eco-tourism zones in mountainous areas, tourism exploitation in beaches and the Son Tra peninsula is also of interest to the city, especially in ensuring safety and cleanliness for people and tourists. guests when swimming in the sea, do not adversely affect 
the marine environment from domestic waste (Da Nang: Green tourism - The key to sustainable development, 2021).

\subsection{Research model}

To give a green tourism improvement model for Da Nang it is important for it to be founded on the normal hypothetical bases that analysts have presented in the previous many years. Notwithstanding, it is likewise important to join these hypotheses with the remarks of homegrown and unfamiliar specialists to display green tourism advancement to be in accordance with the genuine circumstance of Da Nang. At the end of the day, the model of green tourism improvement should be a mix of hypotheses and, what's more, reasonable judgment, which can best recognize the elements influencing green the travel industry in Da Nang. In other words, the model of green tourism improvement should be a blend of hypothesis and down-to-earth judgment, which can best recognize the elements influencing green the travel industry in Da Nang. In that sense, the components influencing green the travel industry can be summed up as follows.
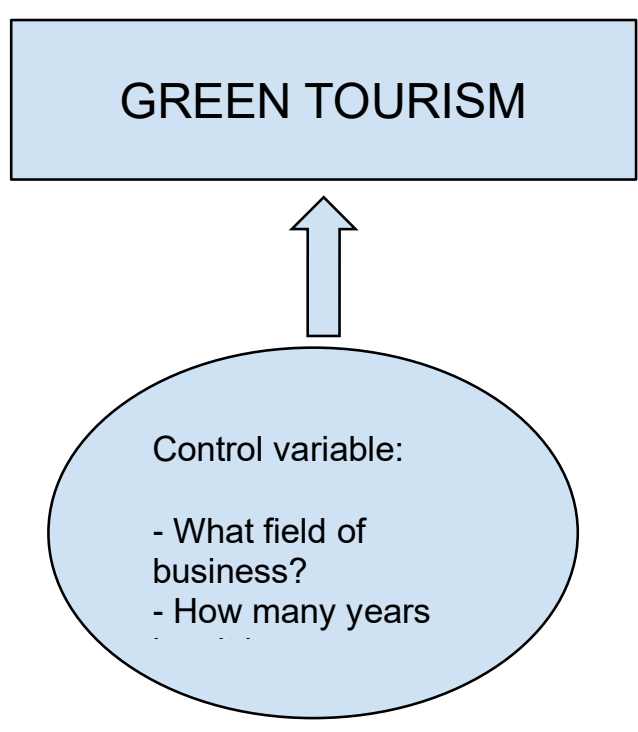

Picture 1. Research model factors affecting green tourism (Proposed Study Team)

Table 1. Official Scale

$\begin{array}{lll}\text { No Factors Items } & \text { Source }\end{array}$

1 Cost C1: The current green tourism model, although popular, has not been developed much in Da Nang. Do you

(VietnamBiz, 
agree that businesses spend money to promote this type 2019) of tourism?

C2: Do you agree that businesses spend a lot of money to invest in GREENTECH (green technology)?

C3: Do you agree that businesses should spend a lot of money investing in public transport (buses, bicycles, ...) in the vehicle system of your business?

2 Green Awareness
GA1: Do you agree that today's environmental problems are very serious?

GA2: Do you agree that many accommodation and travel businesses are now using less environmentally friendly/harmful materials?

GA3:Do you agree that businesses should invest in using green materials, environmentally friendly green products (although its cost might be more expensive)?

GA4: Do you agree that the "Green Tourism" model will make a positive impact on the environment?

GA5:Do you agree that "Green Tourism" (including green hotels/resorts, green tours, green products, ...) is increasingly popular and favored?

GA6: Do you agree that the "Green Tourism" model has the potential to bring great revenue to your business in particular and Danang's economy in general in the future?

GA7: Do you agree that your business should adopt the "Green Tourism" model as a form of sustainable tourism in the near future? 
3 Competitive CA1: Do you agree that in neighboring countries, Advantage Vietnam has been occupying a great advantage with the top position in the tourism industry, especially Da Nang with increasingly ecotourism areas. appear denser?

CA2: Do you agree that Da Nang has the biggest competitive advantage among the central provinces?

(Da Nang

tourism is

competing

strongly with

Phuket and

Bali

Vietnam

CA3:Do you agree that in the central region, Da Nang has been occupying an advantage of the almost leading position in the ecological "smokeless industry" industry, and large resort locations or other types of tourism. Other resorts also developed from there?

CA4: Do you agree that ecotourism compared to other types of tourism in Da Nang is not qualified to combine

Education,

2021) with resort activities in the area?

(Study

competitiven

ess of Da

Nang tourism

destination,

2021)
4 Policy of PG1: Do you think to recognize a "green tourism" Government product, it is necessary to put environmental protection criteria on top? (Environmen

PG2: Do you think tourism businesses and companies 2021) should apply the "set of green tourism criteria" of the Government in the investment and planning process?

PG3: Do you think when applying the "green" knowledge and "clean" technology of countries with the developed green tourism industries in the world and from there apply it to the development of green tourism in Vietnam?

PG4: Do you think the Government's policies on green tourism aim to encourage overseas training of professionals and managers to manage green tourism, green growth, and the green economy?

PG5: Do you think the Government should advance the promotion of green tourism for the whole society to know and understand more about the concept and benefits of green tourism? 
5 Green GT1: Do you agree that tourism development is

Tourism associated with environmental protection, does green tourism have potential in the future in terms of ecosystem conservation?

GT2: Do you agree that green tourism will contribute to improving job opportunities for people in mountainous and remote areas?

GT3: Do you agree that Green Tourism reduces harm and increases the positive impact of travel?

\section{Research Method}

\subsection{Research Methods}

\subsubsection{Qualitative Research Method}

Using Ground theory through the synthesis of previous studies to build theoretical research models and scale.

Survey subjects are business owners dealing in accommodation and travel services in the tourism industry in Da Nang city. A questionnaire is designed with 26 questions, including 4 questions about demographics and 22 questions serving the assessment of factors affecting the implementation of the "Green Tourism" model in the city. Da Nang on a 5-point Likert scale with an increasing positive rating.

\subsubsection{Quantitative Research Method}

Learning and synthesizing theories, articles, research articles, about research issuesto find and synthesize factors affecting the implementation of the "Green Tourism" model in Da Nang city.

\subsection{Sample Size}

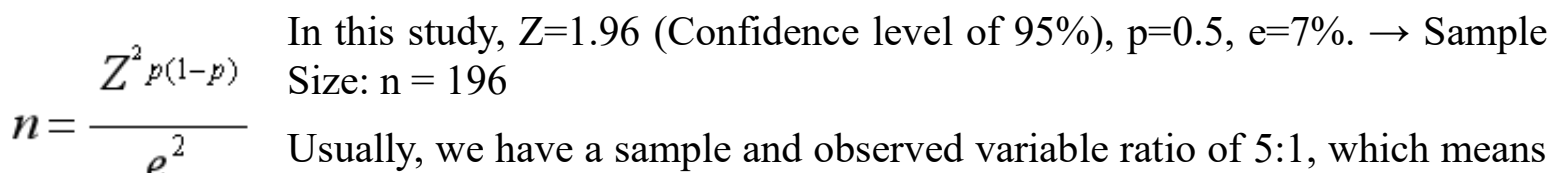
that a measurement variable needs at least 5 observations. The study using 26 variables to measure so $26 * 5=130$ observations. But because of the following-up (Hair, J., Black, B., Babin, B., \& Anderson, R., 2010), increased sample sizes always produce greater power for the statistics test. $\rightarrow$ Study's sample size $n=196$.

\subsection{Sampling}

Because survey subjects are business owners dealing in accommodation and travel services in the tourism industry in Da Nang city. Therefore, the data were collected according to the judgment method. 


\subsection{Research Process}

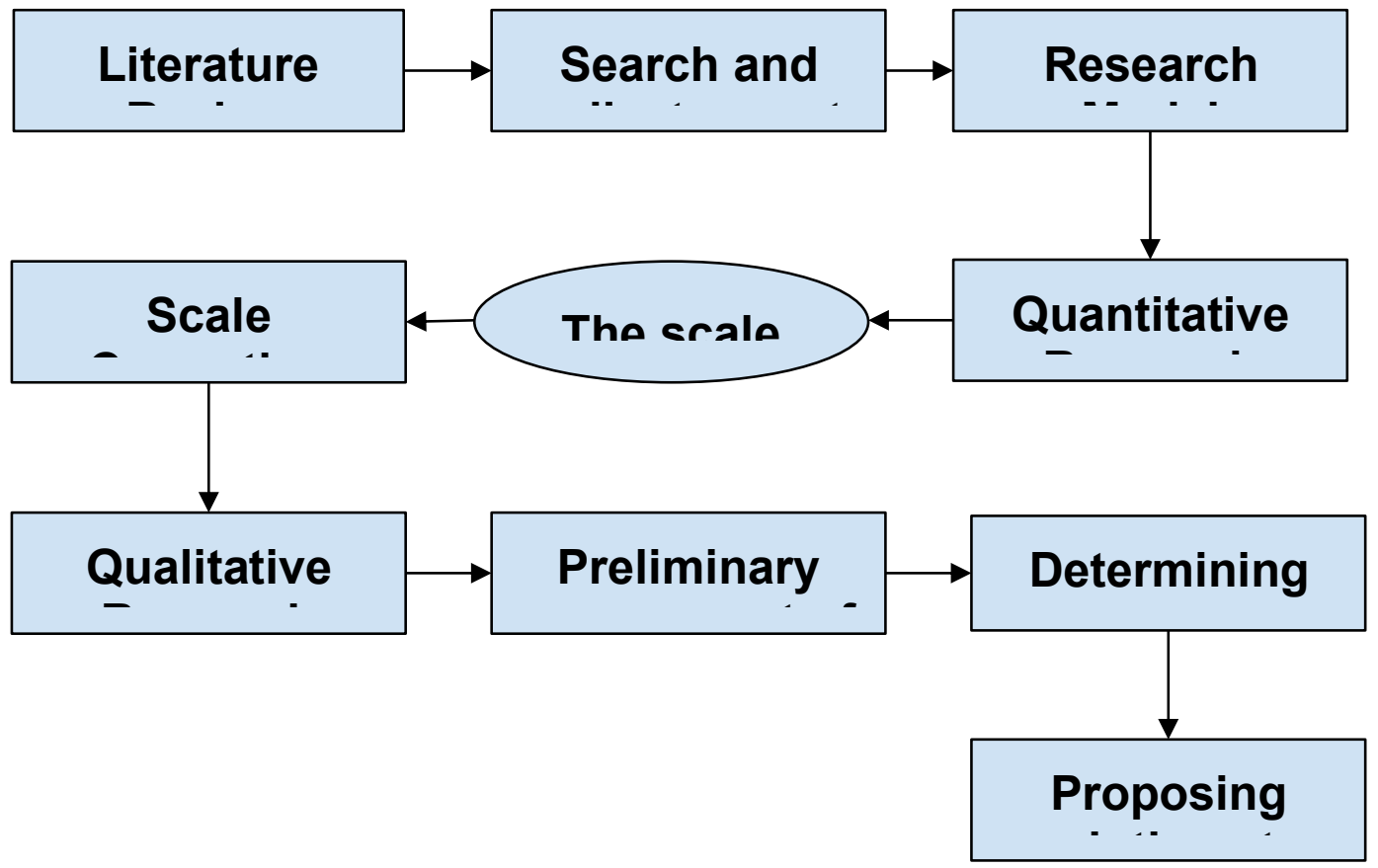

Picture 2. Research Process

\section{Findings and Discussions}

The questionnaire was distributed by 196 business owners dealing in accommodation and travel services in the tourism industry in Da Nang city.

\subsection{Characteristics}

Table 2. Descriptive statistics of demographic factors

\begin{tabular}{l|l|l|l|}
\hline & & \multicolumn{2}{c}{ Percent (\%) } \\
\hline
\end{tabular}




\begin{tabular}{|c|c|c|c|}
\hline & From 6 to 10 years & 86 & $43.9 \%$ \\
\hline & & & \\
\hline & From 10 to 15 years & 17 & $8.7 \%$ \\
\hline & & $\mathrm{T}$ & \\
\hline & Above 15 years & 33 & $16.8 \%$ \\
\hline & & $\mathrm{T}$ & \\
\hline & Total & 196 & 100.0 \\
\hline & & & \\
\hline Which sector of the & Accommodation (hotel, resort, ...) & 42 & $21.4 \%$ \\
\hline $\begin{array}{l}\text { your business operate } \\
\text { in? }\end{array}$ & Restaurant & 50 & $25.5 \%$ \\
\hline & & $\mathrm{T}$ & \\
\hline & Booking & 39 & $20 \%$ \\
\hline & Travel company & 32 & $16.3 \%$ \\
\hline & Others & 33 & $16.8 \%$ \\
\hline & & $T$ & $T$ \\
\hline & Total & 196 & 100.0 \\
\hline What is the number & Under 50 employees & 75 & $38.3 \%$ \\
\hline business? & From 51 to 100 employees & 37 & $18.9 \%$ \\
\hline & From 101 to 150 employees & 14 & $7.1 \%$ \\
\hline & & & \\
\hline & From 151 to 200 employees & 17 & $8.7 \%$ \\
\hline & & $\mathrm{T}$ & \\
\hline & From 201 to 250 employees & 29 & $14.8 \%$ \\
\hline & & & T \\
\hline & Above 250 employees & 24 & $12.2 \%$ \\
\hline & & & \\
\hline & Total & 196 & 100.0 \\
\hline
\end{tabular}




\subsection{Assessing the Reliability of the Scale (Cronbach's Alpha)}

The results showed that variables with Cronbach's coefficient's alpha are greater than 0.6 and have a correlation coefficient of variables greater than 0.4. Variables are used in the subsequent EFA analysis.

Table 3. Summary table of Cronbach's Alpha coefficients of the scales

\begin{tabular}{|c|c|c|c|c|}
\hline No & Items & $\mathrm{N}$ of Items & $\begin{array}{l}\mathrm{N} \text { of Items } \\
\text { satisfying }\end{array}$ & $\begin{array}{l}\text { Cronbach's } \\
\text { Alpha }\end{array}$ \\
\hline 1 & Cost $(\mathrm{C})$ & 3 & 3 & 0.870 \\
\hline & $\Gamma$ & $T$ & & \\
\hline 2 & Green Awareness (GA) & 7 & 7 & 0.947 \\
\hline$\Gamma$ & $T$ & & & \\
\hline 3 & Competitive Advantage (CA) & 4 & 4 & 0.901 \\
\hline 4 & The policy of Government (PG) & 5 & 5 & 0.890 \\
\hline$\Gamma$ & $\Gamma$ & $T$ & $T$ & \\
\hline 5 & Green Tourism (GT) & 3 & 3 & 0.649 \\
\hline
\end{tabular}

\subsection{EFA}

The EFA factor analysis included 19 independent observation variables using the "Principal Component" method and the "Varimax" rotation. The Barlett test result with sig. $=0.000$ is less than 0.005 , and the KMO coefficient of 0.873 is greater than 0.5 after analysis. For Eigenvalues $>1$, the total variance extracted is 75.683 percent $>50$ percent, implying that 75.683 percent of data variations can be explained. This implies that the observed variables have a strong enough correlation to warrant the use of EFA. There are four extracted factor groupings.

Table 4. Results of the EFA analysis from independent observation variables

\begin{tabular}{|c|c|c|c|c|}
\hline \multirow{2}{*}{ Items } & \multicolumn{4}{|c|}{ Factor loading } \\
\hline & 1 & 2 & 3 & 4 \\
\hline GA2 & 0882 & & & \\
\hline
\end{tabular}




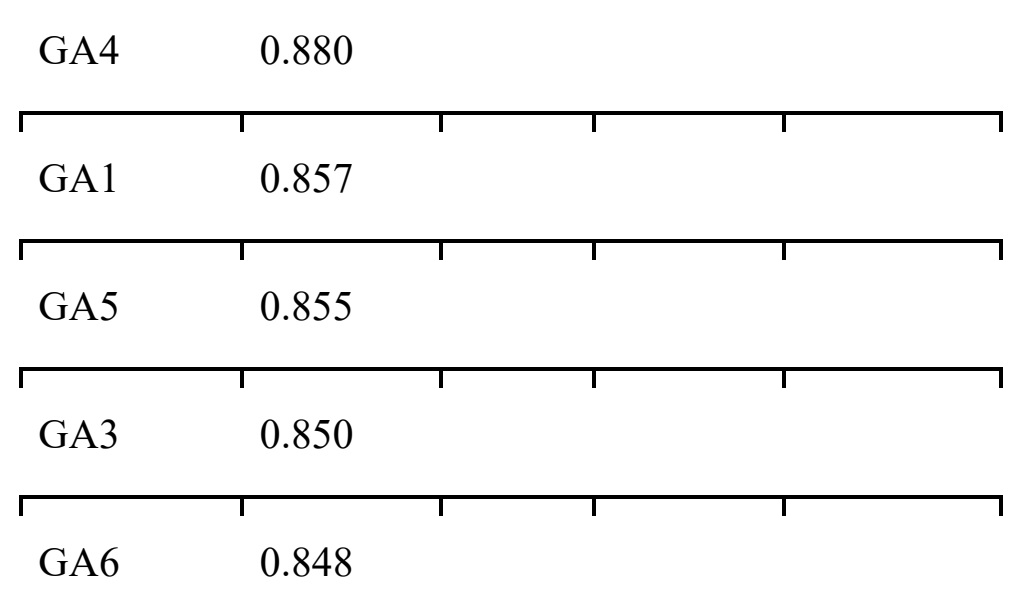

\begin{tabular}{|l|l|l|l|}
\hline GA7 & \multicolumn{1}{|c|}{$\mid$} \\
\hline PG2 & 0.833 & \\
\hline PG4 & & \\
\hline & 0.823 & \\
\hline
\end{tabular}

\begin{tabular}{l|l|l|}
\hline PG3 & 0.800
\end{tabular}

\begin{tabular}{|l|l|l|}
\hline PG5 & 0.792 & \\
\hline
\end{tabular}

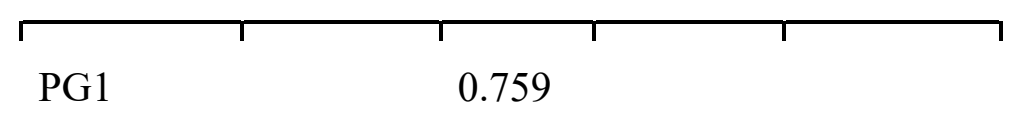

\begin{tabular}{|l|l|l|}
\hline CA2 & \multicolumn{1}{c|}{0.860} \\
\hline CA4 & 1 & 0.856 \\
\hline
\end{tabular}

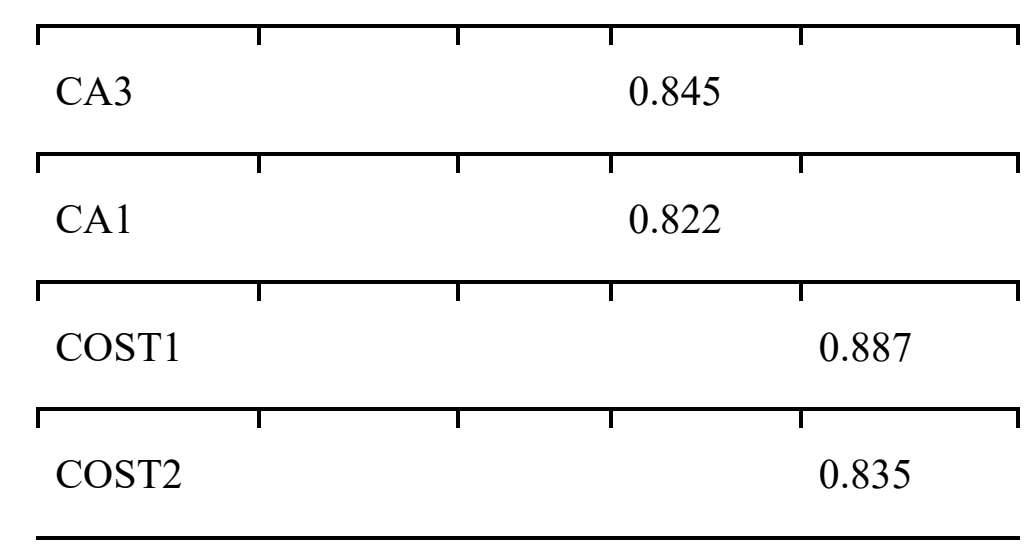


The coefficients satisfy the conditions

\begin{tabular}{|c|c|c|c|c|}
\hline $\begin{array}{l}\text { Cronbach' } \\
\text { s Alpha }\end{array}$ & 0.870 & 0.947 & 0.901 & 0.890 \\
\hline & $T$ & & $T$ & \\
\hline $\begin{array}{l}\text { Eigenvalu } \\
\mathrm{e}\end{array}$ & 5.516 & 3.443 & 3.115 & 2.306 \\
\hline 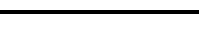 & $\Gamma$ & & & \\
\hline $\begin{array}{l}\text { Cumulativ } \\
\text { e } \%\end{array}$ & $75.683 \%$ & & & \\
\hline KMO & 0.873 & & & \\
\hline $\begin{array}{l}\text { Bartlett's } \\
\text { Test }\end{array}$ & Sig. $=0.000$ & & & \\
\hline
\end{tabular}

Table 5. EFA analysis results for the dependent variables

Factor Loading

1

$\begin{array}{ll}\text { GT1 } & 0.785\end{array}$

GT2

0.766

GT3

0.749

The coefficients satisfy the conditions

Cronbach's Alpha

0.649 
Eigenvalue

1.764

Cumulative \%

$58.816 \%$

$\mathrm{KMO}$

0.654

Bartlett's Test

Sig. $=0.000$

The EFA results show that the three observed variables are extracted into a dependent variable factor, all of which have factor loading factor $>0.5$ and a total extraction variance of 58.816 percent, with only KMO number is 0.654 good with significance level Sig. $=0.000$ in the Barlett test and the quantity Eigenvalue $=1.764$ satisfying the condition. As a result, these detected factors are kept for further investigation.

\subsection{Correlation Matrix}

Table 6. Correlation between variables

\begin{tabular}{|c|c|c|c|c|c|c|}
\hline & & $\mathrm{Y}$ & $\mathrm{X} 1$ & $\mathrm{X} 2$ & $\mathrm{X} 3$ & $\mathrm{X} 4$ \\
\hline \multirow[t]{3}{*}{ Y } & $\begin{array}{l}\text { Pearson } \\
\text { Correlation }\end{array}$ & 1 & $.558^{* *}$ & $.451 * *$ & $.417 * *$ & $.567^{* *}$ \\
\hline & $\begin{array}{l}\text { Sig. } \\
\text { tailed) }\end{array}$ & & .000 & .000 & .000 & .000 \\
\hline & $\mathrm{N}$ & 196 & 196 & 196 & 196 & 196 \\
\hline \multirow[t]{3}{*}{$\mathrm{X} 1$} & $\begin{array}{l}\text { Pearson } \\
\text { Correlation }\end{array}$ & $.558^{* * *}$ & 1 & .090 & -.036 & .120 \\
\hline & $\begin{array}{l}\text { Sig. } \\
\text { tailed })\end{array}$ & .000 & & .208 & .613 & .094 \\
\hline & $\mathrm{N}$ & 196 & 196 & 196 & 196 & 196 \\
\hline $\mathrm{X} 2$ & $\begin{array}{l}\text { Pearson } \\
\text { Correlation }\end{array}$ & $.451 * *$ & .090 & 1 & .014 & .042 \\
\hline
\end{tabular}




\begin{tabular}{|c|c|c|c|c|c|c|}
\hline & $\begin{array}{l}\text { Sig. } \\
\text { tailed) }\end{array}$ & .000 & .208 & & .846 & .555 \\
\hline & $\mathrm{N}$ & 196 & 196 & 196 & 196 & 196 \\
\hline \multirow[t]{3}{*}{ X3 } & $\begin{array}{l}\text { Pearson } \\
\text { Correlation }\end{array}$ & $.417^{* *}$ & -.036 & .014 & 1 & -.061 \\
\hline & $\begin{array}{l}\text { Sig. } \\
\text { tailed) }\end{array}$ & .000 & .613 & .846 & & .398 \\
\hline & $\mathrm{N}$ & 196 & 196 & 196 & 196 & 196 \\
\hline \multirow[t]{3}{*}{$\mathrm{X} 4$} & $\begin{array}{l}\text { Pearson } \\
\text { Correlation }\end{array}$ & $.567^{* * *}$ & .120 & .042 & -.061 & 1 \\
\hline & $\begin{array}{l}\text { Sig. } \\
\text { tailed })\end{array}$ & .000 & .094 & .555 & $98^{.3}$ & \\
\hline & $\mathrm{N}$ & 196 & 196 & 196 & 196 & 196 \\
\hline
\end{tabular}

**. Correlation is significant at the 0.01 level (2-tailed).

*. Correlation is significant at the 0.05 level (2-tailed).

According to the correlation matrix in the table above, there is a linear connection between $\mathrm{Y}$ dependent variables and independent variables X1, X2, X3, X4, X7 since the Sig significance level is 0.00 , less than 0.05 . As a result, the usage of these linear regression analysis variables is suitable.

\subsection{Multiple Regression Analysis}

Table 7. Estimate the beta coefficient of the model by the Enter method

\begin{tabular}{l|l|lll}
\hline Model & $\begin{array}{l}\text { Unstandardized } \\
\text { Coefficients }\end{array}$ & $\begin{array}{l}\text { Standardized } \\
\text { Coefficients }\end{array}$ & Sig. & $\begin{array}{l}\text { Collinearity } \\
\text { Statistics }\end{array}$ \\
\hline
\end{tabular}




\begin{tabular}{|c|c|c|c|c|c|c|c|c|}
\hline & & B & $\begin{array}{l}\text { Std. } \\
\text { Error }\end{array}$ & Beta & & & $\begin{array}{l}\text { Toler } \\
\text { ance }\end{array}$ & VIF \\
\hline 1 & (Constant) & -.041 & .068 & & -.608 & .544 & & \\
\hline & $\mathrm{X} 1$ & .258 & .011 & .478 & 23.796 & .000 & .977 & 1.023 \\
\hline & $\mathrm{X} 2$ & .236 & .012 & .379 & 19.023 & .000 & .990 & 1.010 \\
\hline & X3 & .245 & .011 & .461 & 23.180 & .000 & .995 & 1.005 \\
\hline & $\mathrm{X} 4$ & .245 & .009 & .521 & 26.022 & .000 & .981 & 1.019 \\
\hline
\end{tabular}

Adjusted R Square $=0.923$;

$\mathrm{F}(\mathrm{ANOVA})=587.381$;

Sig. $(A N O V A)=0.000$;

Durbin - Watson $=2.065$.

The results of the ANOVA analysis reveal that the statistical value $\mathrm{F}=587.381$ with the value sig $=0.000$ demonstrates that the regression model is appropriate for the data set. DurbinWatson is $1<2.065$, showing no correlation between variables in the model. When the VIF of all variables is 1 , it implies that no collinearity exists. The corrected R2 coefficient is 0.962 , indicating that the independent factors explain $92 \%$ of the variation in the dependent variable.

The standardized regression equation: $\mathrm{Y}=-0.041+0.478 \mathrm{X} 1+0.379 \mathrm{X} 2+0.461 \mathrm{X} 3+0.521 \mathrm{X} 4$. The 4 factors that were originally set were accepted.

\subsection{Verification of Conformity of the Model}

Scatterplot scatter plots demonstrate that the residual dispersing randomly about the route passes through zero degrees and varies significantly in the $+/-1$ range, demonstrating that the linear relation assumption is not broken. The histogram displays the standard distribution curve superimposed on the frequency chart, a very tiny mean value close to 0 (mean $=1.12 \mathrm{E}$ 14 ), and a standard deviation close to 1 (Std. Dev $=0.990)$, suggesting the approximate residual distribution. The P-P plot also indicates that the perspectives do not deviate too much from the predicted straight line, implying that the residual distribution with standard distribution is not violated. As a result, the linear regression model presented above is an appropriate model. 


\subsection{Test Relationship between Geographic Information and Green Tourism}

Based on the One-Way ANOVA mean difference analysis technique for awareness of green tourism, the number of years the business has been in operation, which industry the business is in, and how many employees the business has. The author discovered that there is a statistically significant variation in the motivating variables of respondents from different the number of years the business has been in operation, which industry the business is in, and how many employees the business has. There was no statistically significant variation in motivation variables for awareness of green tourism.

\subsection{Discussion}

The author used a combination of qualitative and quantitative research methods, numerical processing, and analysis using SPSS 20.0 software to identify 04 factors affecting the implementation of the "green tourism" model in Da Nang of business owners providing accommodation and travel services in the tourism industry in Da Nang city. And those factors are arranged in descending order of impact as follows: Cost; Green awareness; Competitive advantage; Government policies; The result is Green Tourism and offers a range of objective solutions.

\subsection{Recommendation}

\section{Solution implications for the Cost:}

- To diminish costs fundamentally, we have been offering a wide range of arrangements and strategies: $100 \%$ of the lodging's high temp water is created from the solar system. Notwithstanding other significant measures like utilizing power for lighting successfully, diminishing water utilization, limiting the utilization of plastic materials, focusing on the utilization of reused paper, and all the more viably overseeing byproducts.

- Waste and synthetic compounds have consistently assumed a significant part in our assurance to secure the climate, which has carried extraordinary effectiveness to the travel industry administration industry.

\section{Solution implications for Green Awareness:}

- To restore and protect the marine ecosystem, Da Nang needs to implement many solutions such as: Prohibiting polluting activities; collecting floating waste, especially garbage at the foot of the island; a sandbank is a place where coral reefs are often distributed... Da Nang Management Board coordinates with the People's Committee of Da Nang city and related sectors, so it often regularly implement activities: propagandize, remind and guide watercraft not to anchor on coral reefs; patrolling, preventing fishing in the prohibited areas, strictly handling the act of fishing at the wrong place, especially the act of catching with the form of destructive tools.

- For tourists If you are experiencing sea tourism in Da Nang, it is necessary to propagate as well as remind them about selling corals as gifts and limiting direct contact with corals, because taking corals as souvenirs as well as contributing 1 coral reef destruction. 


\section{Solution implications for the Competitive Advantage:}

- Cooperate with other green tourism models in the area of Da Nang in particular and Vietnam in general to promote the potential, and especially promote to domestic and foreign tourists to know about the outstanding model. this, and could have a positive impact on today's tourism industry worldwide.

\section{Solution implications for the Policy of Government:}

- Submit a petition to support private loans in the field of tourism services for a period of 3-5 years with low-interest rates in the form of unsecured loans with the condition that people legally reside in Da Nang city Nang. Linking with other localities to increase the potential and develop domestic tourism

- The government needs to create support packages for small and medium-sized businesses in the tourism service industry to inspire and contribute to maintaining the tourism potential in Da Nang.

\subsection{Conclusion}

The research has achieved the target that finds four significant factors positively affecting tourism potential with the green tourism model in Danang. Based on articles, surveys, and research papers, this study has established a theoretical model of 5 factors with 22 items impacting tourism potential with the green tourism model in Danang. It has used a multivariable regression model of Kovach on 196 survey samples and identified 4 major factors which have statistically significant effects, including(1) Cost; (2) Green Awareness; (3) Competitive Advantage; (4) Policy of Government. Furthermore, the study makes suggestions based on four coefficient variables and their relationships to other things generated from the model's results.

\subsection{Limitations:}

Limitation 1: This study focuses only on Da Nang, and with future expansion to surrounding areas of Da Nang. The main audiences involved include university students, employees of tourism service enterprises, and those equipped with levels and qualifications from intermediate, college, and university levels.

Limitation 2: Because this study was conducted in the context of the Covid-19 epidemic, the results and research process will not be accurate with reality. And the actual survey with customers or related subjects is not feasible, so the research results will not reflect $100 \%$ of reality.

\section{References}

Da Nang won the title of Vietnam's National Green City', The Electronic Portal of City. [online] Available at: <https://danang.gov.vn/chitiet?id=31979\&_c=3\%2C9\&fbclid=IwAR3cH_RPtOo_AMcLCEEijE3UGJp8o1A4BxcS_4fH62rd13r16uieWF1E50> [Accessed 12 Jul. 2018]

Responses to the International Ecotourism Society's September 2019 survey', The International Ecotourism Society 2019. [online] Available at: $<$ https://ecotourism.org/news/responses-to-the-international-ecotourism-societys-september2019-survey/> [Accessed 25 Sep. 2019] 
Hang Nga 2021. Green tourism: A guarantee for sustainable tourism development', The Vietnamnet. [online] Available at: <https://vietnamnet.vn/vn/goc-nhin/du-lich-xanh-su-baodam-cho-phat-trien-du-lich-ben-vung-

724752.html?fbclid=IwAR32bCOR2IrjBKFIOiB16PWIZXgj6U1_A0Odlj7nGeJEfpfm7eQx1 L71ywU> [Accessed 17 May. 2021]

Ha Phuong 2019. Green tourism and difficult obstacles', The Economy \& Urbanism. [online] Available at: $<$ https://kinhtedothi.vn/du-lich-xanh-va-nhung-chuong-ngai-kho-vuot339662.html?fbclid=IwAR0GjN5U2LtDA2DVVHXzcAyjiz8ULg0yMYjVpfkCM1ZogNMV Iug_lc4IGrk> [Accessed 30 Mar. 2019]

Anon 2021. What is green tourism or ecotourism? Ecotourism trends in the future. VIME Garden. Available at: <https://vimegarden.vn/du-lich-xanh-hay-du-lich-sinh-thai-la-gi-xuhuong-du-lich-sinh-thai-trong-tuong-lai/> [Accessed 16 Sep. 2021].

Anon 2021. Singapore - The green - clean - beautiful tourism country | FOCUS ASIA TRAVEL. [online] Available at: $<$ https://focusasiatravel.vn/singapore-dat-nuoc-du-lich-xanhsach-dep/> [Accessed 16 Sep. 2021].

Japan supports Da Nang to build automatic public transport, 2017. Nhật Bản hỗ trọ Đà Nã̃ng xây dưng giao thông công công tụ động. [online] Available at: <https://viettimes.vn/post64660.html $>$ [Accessed 6 Oct. 2021].

Discover the 'green' Da Nang, 2021. Khám phá Đà Nã̃ng ““xanh”. [online] hanoimoi.com.vn. Available at: <http://www.hanoimoi.com.vn/tin-tuc/Dulich/1005775/kham-pha-da-nang-xanh $>$ [Accessed 5 Oct. 2021].

Da Nang: Green tourism - The key to sustainable development, 2021. Đà Nã̃ng: Du lịch xanh - Chì khóa phát triển bền vũng - Tổng cuc Du lịch. [online] Tổng cục Du lịch Việt Nam. Available at: <https://vietnamtourism.gov.vn/index.php/items/36235> [Accessed 5 Oct. 2021].

Environmental magazine, T. chí D., 2021. Phát triển du lịch xanh Việt Nam. [online] Tạp chí du lịch. Available at: <http://vtr.org.vn/phat-trien-du-lich-xanh-viet-nam.html $>$ [Accessed 20 Sep. 2021].

Anon 2021. Travel Competitor Analysis - CRIF D\&B Vietnam. [online] CRIF D\&B VIETNAM LLC. Available at: $<$ https://dnbvietnam.com/tu-van/phan-tich-doi-thu-canh-tranhcua-du-lich.html $>$ [Accessed 6 Oct. 2021].

Anon n.d. Competitive advantage in tourism development in Vietnam and some central provinces - Institute for Tourism Development Research (ITDR). Available at: $<$ http://itdr.org.vn/loi-the-canh-tranh-phat-trien-du-lich-viet-nam-va-mot-so-tinh/> [Accessed 6 Oct. 2021].

VietnamBiz, 2019. What is Green Tech? Green technology in business and investment activities. [online] vietnambiz. Available at: $<$ https://vietnambiz.vn/cong-nghe-xanh-greentech-la-gi-cong-nghe-xanh-trong-hoat-dong-kinh-doanh-va-dau-tu-20191017113929332.htm> [Accessed 6 Oct. 2021].

Tourism development research institute, n.d. Nghiên cứu trao đổi về Du lịch Xanh tại Việt Nam hiện nay: Bài học kinh nghiệm của Thái Lan và triển vọng trong tương lai - Viện Nghiên cứu Phát triển Du lịch (ITDR). Available at: <http://itdr.org.vn/nghien_cuu/nghien- 
cuu-trao-doi-ve-du-lich-xanh-tai-viet-nam-hien-nay-bai-hoc-kinh-nghiem-cua-thai-lan-vatrien-vong-trong-tuong-lai/> [Accessed 20 Sep. 2021]

Enhancing the competitiveness of Vietnam's tourism, 2021. Phát triển du lịch xanh: Bài 2: Nâng cao súc cạh tranh của du lịch Việt Nam. [online] Available at: <https://bnews.vn/phattrien-du-lich-xanh-bai-2-nang-cao-suc-canh-tranh-cua-du-lich-viet-nam/143515.html> [Accessed 20 Sep. 2021].

Anon 2021. Da Nang tourism is competing strongly with Phuket and Bali - Vietnam Education. [online] Available at: < https://giaoduc.net.vn/gdvn-post204038.gd $>$ [Accessed 20 Sep. 2021].

Anon 2021. Study the competitiveness of Da Nang tourism destination. [online] xemtailieu.net. Available at: <//xemtailieu.net/tai-lieu/nghien-cuu-nang-luc-canh-tranh-diemden-du-lich-da-nang-126601.html $>$ [Accessed 20 Sep. 2021].

Hair, J., Black, B., Babin, B., \& Anderson, R. (2010). Multivariate data analysis 7th Pearson prentice hall. Upper Saddle River, NJ.

\section{Copyrights}

Copyright for this article is retained by the author(s), with first publication rights granted to the journal.

This is an open-access article distributed under the terms and conditions of the Creative Commons Attribution license (http://creativecommons.org/licenses/by/4.0/) 